\author{
Serhiy Lyeonov, \\ D.Sc., Sumy State University, Ukraine \\ Olha Kuzmenko, \\ D.Sc., Sumy State University, Ukraine \\ Hanna Yarovenko, \\ Ph.D., Sumy State University, Ukraine \\ Tatiana Dotsenko, \\ Sumy Regional Branch №10018 / 0172 of Oschadbank, Ukraine
}

\title{
THE INNOVATIVE APPROACH TO INCREASING CYBERSECURITY OF TRANSACTIONS THROUGH COUNTERACTION TO MONEY LAUNDERING
}

\begin{abstract}
A current task is to provide the economic security of any country in the context of creating effective and reliable measures of the banking cybersecurity system against money laundering. First of all, it relates to the fact that the money laundering processes and financing of terrorism negatively influence the economy of any country and reduce the economic security level. Secondly, the high level of money laundering in the country promotes the emergence of such negative processes as corruption, extortion, drug production, people smuggling, gangsterism, terrorism, which leads to an increase of the crime situation in the country and endangers the lives of the population. Thirdly, the existing cybersecurity measures of banks do not affect the security of transactions in a timely manner to identify funds obtained illegally. Therefore, exactly this aspect is required changes and modernization in order to accomplish the task. The aim of the article is to develop the innovative scientific and methodic approach to the country's attractiveness modelling for proceeds laundering by other countries. This technique is one of the tools of the bank's cybersecurity system for making further decisions regarding the risk of legalization. In order to solve this problem authors suggest the approach, which is based on gravity modelling. Eight factors: Gross Domestic Product per capita, Claims on the central government, Internally displaced persons, associated with conflict and violence; Automatic Exchange of Information; Corruption Perceptions Index; Global Terrorism Index; Legatum Prosperity Index; Happy Planet Index are proposed to be evaluated using the expert approach to implement the above approach. Then the integral indicator is calculated using the Minkowski metric and taking into account the factors normalization. Using the gravity model, the country's attractiveness degree considering is defined for proceeds laundering on the part of another country. Data for 105 countries are used for calculation and results for Ukraine. Poland and Germany are represented. As a result, we can see that developed countries with high welfare level are attractive for developing countries for money laundering, countries with low welfare level, low economic development and unstable political situation are attractive for the developed countries. The proposed methodology is recommended to be introduced in the activity of banks' cybersecurity systems. It will allow identifying transactions of those countries for which the risk of legalization is high and introduce additional monitoring to regard the legitimacy of their financial sources. In addition, it is expedient to use the model in the activities of the country's regulatory authorities, which will promote the introduction of cybersecurity standards and increase the ethics of financial relations between countries.

Keywords: cybersecurity, money laundering, gravity modelling, country attractiveness, risk, expert approach,
\end{abstract} normalization, Minkowski metric.

Introduction. The world economy and globalization development, the economic welfare achievement, increasing the living standards and the life safety of the population are important issues of today's world community. However, in this development process, there are more opportunities for free money movement by criminals and terrorists simultaneously with increasing of operations at the financial markets, trade flows growth, the increase of assets, money. The illegal funds turnover, financing of terrorism and organized crime become the most significant problems, which threaten economic of any

Cite as: Lyeonov, S., Kuzmenko, O., Yarovenko, H. \& Dotsenko, T. (2019). The Innovative Approach to Increasing Cybersecurity of Transactions Through Counteraction to Money Laundering. Marketing and Management of Innovations, 3, 308-326. http://doi.org/10.21272/mmi.2019.3-24 
S. Lyeonov, O. Kuzmenko, H. Yarovenko, T. Dotsenko. The Innovative Approach to Increasing Cybersecurity of Transactions Through Counteraction to Money Laundering

country. The country' banking system is involved in this process because through it financial transactions are carried out. The level of organization of the banking cybersecurity system affects how quickly legal funds can be detected or transactions involving illegal sources cannot be allowed. A high level of security reduces the risk of financing terrorism. Therefore, one of the tasks of cybersecurity is to ensure the safety of transactions. It is possible only through the compliance with safety standards which should also relate to the ethics of transactions conducted from other countries.

Recently, in the international economic community much efforts is oriented to study and to measure the relationship between economy, policy and organized crime. Efforts to prevent the financing of such a relationship have to go beyond the boundaries of one country in order to track and to block the money flows, wherever they may be hidden. The money laundering processes, money shadowing, financing of terrorism negatively influence the economic security in any country, undermine its economic system and lead to the disbalance in the society and life safety. Specialists and scientists in the economic literature make some attempts for the quantitative evaluation of processes, which relate to the money laundering. However, the sufficiency and adequacy of these models are difficult to estimate, because money laundering is rather secret and invisible.

Literature Review. Gabriel Andruseac (Andruseac, 2015) and Miles Kahler (Kahler, 2006) analyze the globalization impact, which forms the international environment, on the economic security, show the close relationship between economic globalization and undesired economic and political consequences, revealing the new approaches in this context. Bowman Dina and Van Kooy John (Bowman and Van Kooy, 2016) propose some boundaries to show the relationship of various levels, spheres, factors, which have impact on the economic security, allowing them to focus on the disadvantageous position at the labour market and on the economic danger, defining the wider systematic and structural impact on these issues at the same time. Such scientists as Marius-Petre Rotaru (Rotaru, 2009) and Peter Navarro (Navarro, 2018) compare economic and national security, describing the economic security as an organic dimension of national security.

In modern science, considerable attention is paid to various aspects of cybersecurity taking into account the development of digital society, informatization and automation of all processes of economic agents. This question is considered at international conferences. So, the issues of IT security, network security, information security and cybersecurity technologies and solutions for financial sector will be presented on 12-13 November 2019 in Istanbul Turkey (IFINSEC Financial Sector IT Security Conference and Exhibition, 2019). The most crucial directions were discussed at the conference «EBF Cybersecurity Conference: Managing Risk. Deploying Awareness» in 2017 in Brussels. It was debated about facilitating the dialogue between banks, regulators and supervisors for more effective implementation of cybersecurity-related measures, exchanging on the challenges faced by banks in managing cyber risk (EBF Cybersecurity Conference: Managing Risk. Deploying Awareness, 2019).

Moreover, the last tendency of human factors influences on cybersecurity will be presented on the $10^{\text {th }}$ International Conference on Applied Human Factors and Ergonomics, which will be organized on 24-28 July 2019 in Washington. The issues of the conference will be focused on the social, economic and behavioural aspects of cyberspace (The 10th International Conference on Applied Human Factors and Ergonomics, 2019). The modern research directions of human-computer interaction will be shown on the

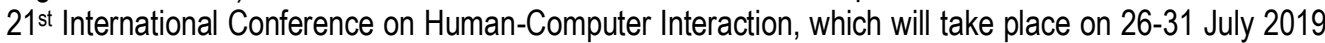

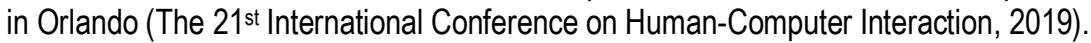

The research of Melissa Hathaway (Hathaway, 2008) on the cybersecurity issues as the most serious problem of economic and national security, deserves special attention. The investigation of challenges, solutions and trends in banking cybersecurity is carried out by Rachael Fernandez, Salma Shalaby, Noora Fetais (Fernandez et al., 2018). In the article by Ricky Leung is studied about global cybersecurity regulation in the banking sector (Leung, 2018). The impact of cybersecurity incidents on financial 
S. Lyeonov, O. Kuzmenko, H. Yarovenko, T. Dotsenko. The Innovative Approach to Increasing Cybersecurity of Transactions Through Counteraction to Money Laundering

institutions was analyzed by a group of authors from General Global Assistance and Identity Theft Resource Center (Fiorentino et al., 2018).

The investigation of general theoretical and practical aspects on anti-money laundering and antifinancing of terrorism, their influence on the economic security is carried out by such scientists as Stefan D. Haigner (Haigner et al., 2012), Schneider Friedrich (Schneider, 2017), Mankiw N. (Mankiw, 2018), Frederic S. Mishkin (Mishkin, 2016) etc. In the article of Buriak A., Lyeonov S., Vasylieva T. relationship of the banking system stability and the money laundering process, as a result of which there is a negative impact on the country's banking system, economic and cybersecurity, is studied (Buriak et al., 2015). Vasylieva T., Lyeonov S., Lyulyov O., Kyrychenko K. observe the impact of different disbalances, among which money laundering and financing of terrorism are defined, on the country's overall economic development (Vasylieva et al., 2018). Besides, authors (Lyeonov et al., 2018; Vasilyeva et al., 2013) assess the degree of the money laundering process impact on the financial sector and macroeconomic stability evaluation in countries of lower-middle-income economies, which greatly undermine the country's economic security level.

A number of scientists in their works observe some aspects to counteract the money laundering and financing of the terrorism, analyze the banking service for money laundering and financing of terrorism, financial operations, actions, give recommendations, particularly: risks of modern technologies for payments, risks of mobile banking operations, electronic payments, money laundering through Internet, regulation of mobile funds (Popa, 2012; Souto, 2013; Stokes, 2013; Vlcek, 2011), problems to estimate tendencies, scales and character, evaluation of the cybercrime and provision of the economic cybersecurity (Anderson et al., 2013; Independent report «2011 report by industry and government on the cost of cybercrime», 2011; Levi, 2017), global oversight and monitoring of the financing of terrorism, money laundering and tax evasion, problems with financial transactions taxation (D'Souza, 2012; Levi et al., 2014; Immordino and Russo, 2016; Matheson, 2011), recommendations (Nart, 2018), oriented to reduce the incomes sources for financing of terrorism.

Peculiarities to finance the international terrorism and transnationally organized crime nature, their sources and methods, international cooperation development in the field to control money laundering and financing of terrorism are analyzed in works of Schneider F. and Caruso R. (Schneider and Caruso, 2011), Blauvelt A. (Blauvelt, 2015), and others (UNODC-31, 2011; Vashchekina, 2018). Great attention of authors (Appel, 2015; Bunker and Sullivan, 2014; Unita di Informazione Finanziaria, 2016; European Banking Federation, 2016; Groupe d'action financière, 2007; Governor of the Central Bank of Tunisia, 2017) is paid to the specific nature of the financial systems regarding the money laundering risks in different countries in the world:

- The EU, which tries to create the only one financial services market in the European Union, to support policy, which will increase the holistic approach use and will provide the regulation to be transferred to the digital reality for financial services;

_ $\quad$ in Italy measures, which are oriented to assess money laundering operations and tendencies, a vulnerability in the economic and financial systems, and risks, relating to the geographical regions, payment tools and economic sectors are investigated. Recently new directions of the quantitative studies, which use econometrics to reveal abnormalities and new tendencies, have been introduced;

- $\quad$ in Greece the regime to launder money and to counteract financing of terrorism, based on Forty Recommendations 2003 and Nine Special Recommendations on the financing of terrorism 2001 of the Financial Action Task Force (FATF) is performed;

- Tunisia concentrates efforts on its financial system integrity, and its investment climate attractiveness, which will form a base of the national obligation to control money laundering and financing of terrorism, based on the strategic variant to prevent its financial sector illegal use, etc. 
S. Lyeonov, O. Kuzmenko, H. Yarovenko, T. Dotsenko. The Innovative Approach to Increasing Cybersecurity of Transactions Through Counteraction to Money Laundering

A number of models are proposed to study the global money laundering, income from transnational crime, flowing through the financial system in the world, the money laundering impact on the banking system stability, economic security and risks evaluation in banks. The econometric models (Mazloumfard and Glans, 2017), liquidity stress testing (Krykliy and Luchko, 2018), Data Mining (Subeh and Yarovenko, 2017; Dean et al., 2017; Kirichenko et al., 2017), structured modeling (Vorontsova et al., 2018) are the most popular models.

Gravity modelling deserves special attention. Authors (Anderson, 2011; Asgharzadeh et al., 2018; Wee and Pearce, 2015; Kuzmenko, 2013a; Kuzmenko, 2013b) from all over the world paid attention to that model, determining that gravity models are used in various social and economic sciences to predict and to describe specific behaviour forms, based on the analogy with Isaac Newton's law of gravitation. Gravity models provide the assessment of flows between two and more places. Although such models are not able to perform an accurate prediction of flows, they form criterion, by which actual observed values are compared, emphasizing in which places flows are unexpectedly high or low. Over the decades the conventional gravity model is successfully used for the various flows; it describes social and economic relationships between spatial objects (Ferwerda et al., 2011).

Walker John the Walker Gravity Model (Walker and Unger, 2009) is the first proposed model to evaluate money laundering all over the world and was based on the well-known gravity model, which is popular in the trade. This model enables to evaluate the illegal funds flows all over the world and describes the allocation geography of proceeds of crime, which are necessary to launder in order to hide their criminal origin. The Gravity Model for Measuring Money Laundering and Tax Evasion by Brigitte Unger also helps to assess the illegal funds flows from one and to every jurisdiction all over the world, and is a changed equation of Walker via updating and adjusting the distance indicator (Unger, 2009). The Gravity Model for Trade-based Money Laundering is used to predict the illegal flows of money laundering. The conventional gravity models borrowed from the international trade theory, are used in it. The model has straight-line logical character, but not a combination of the additional and multiplicative variables (Ferwerda et al., 2011). Isis Economic Model (Brisard and Martinez, 2016) is based on the territorial administration, which is able to provide the financial self-sufficiency and variety of resources, the main strategy of which consists in the fact that the state wealth is the main constituent and financing source of all internal and external operations, and reliable financial resources, value of which is not changed at any time.

Although many efforts are made in the study of the criminal operations with money, a few effective systems to control the financial system in the money laundering the financing of terrorism, have been investigated. Therefore, there are no instruments, which let to prevent money laundering processes. It causes the undermining of the country's economic security. The economy of money laundering, oriented to study scales and impact of the illegal funds, is a rather new field and requires deeper investigation. The gravity modeling issue to assess the money laundering risk and risk of financing of terrorism by one country in another one, as one of bancing cyber security system tools especially in the context of raising the level of economic safety, is of urgent attention.

Methodology and research. A set of data for 215 countries for 2017 was formed to carry out the research. The data consist of statistic information, obtained from the official sites of the world organizations. The authors took 8 indicators: from the official site of the World Bank - Gross Domestic Product per capita (GDP), Claims on the central government (CCG), Internally displaced persons, new displacement associated with conflict and violence (number of cases) (IDP) (World Bank Open Data, 2017); according to data of the Organisation for Economic Co-operation and Development - Automatic Exchange of Information (AEOI) (Organisation for Economic Co-operation and Development, 2017); from the site of Transparency International organization - Corruption Perceptions Index (CPI) (Transparency International, 2017); from studies of Institute for economics \& peace - Global Terrorism Index (GTI) 
S. Lyeonov, O. Kuzmenko, H. Yarovenko, T. Dotsenko. The Innovative Approach to Increasing Cybersecurity of Transactions Through Counteraction to Money Laundering

(Institute for economics \& peace, 2017); from reports, presented on-site of The Legatum Institute Legatum Prosperity Index (LPI) (The Legatum Institute, 2017); from calculations of Happy Planet Index Happy Planet Index (HPI) (Happy Planet Index, 2017).

The selection of the above indicators is caused by the following statements:

1) Happy Planet Index describes the level of citizens' welfare in the country from a position of life satisfaction, ecological security level, the state of medicine etc. Authors suppose that countries, where happy citizens live, are the most attractive for those countries, which launder money since they have more credibility thanks to life stability. The factor is a disincentive since money laundering risk with indicator growth is reduced;

2) Legatum Prosperity Index is a country's welfare indicator, which shows various parameters: economy, governance, education, health, security, ecology etc. We take the difference between the welfare of the country, which launders money, and country, in which money will be laundered. The greater the difference between the welfare of the countries, the better the conditions for money laundering. This indicator is disincentive, but since it is used in the dominator, it will be considered as a stimulator.

3) GDP per capita in the country shows the level of its economic welfare, citizens' financial solvency. If this indicator increases, the goods and services production amount will grow, the country will have favourable conditions for other countries, which try to launder money that reduces the risk level. This indicator is a factor-destimulator disincentive;

4) Automatic Exchange of Information describes the process of the financial information exchange between banks and tax authority. If countries are not involved in this system, the laundering risk will be reduced for countries, which try to launder money. Otherwise, if the country joins this system, the security level of information and its reliability will be increased. The money laundering risk grows in countries, which launder money since the unfavourable environment is formed for them. This factor is stimulator in the model;

5) Claims on the central government prove the trusting degree to the central government regarding its financial obligations. Countries with a high level of trust form favourable conditions to launder the proceeds of crime. Therefore for laundering countries, this factor will probably point the money laundering risk reduction. The indicator is destimulator disincentive in the model;

6) Internally displaced persons, new displacement associated with conflict and violence is a factorstimulator, which proves the instability in the country, a higher level of danger to allocate financial resources. From the position of those, who launder proceeds of crime, military conflicts, violence, which cause the moving of people, create unfavourable conditions for money laundering. It means that increase of this indicator will cause the higher level for money laundering by another country;

7) Corruption Perceptions Index is a factor- disincentive in the model since it demonstrates the efficiency of the law enforcement bodies' work to reveal the corruption. There are favourable conditions for financial flows allocation in the countries with a high level of this indicator. They are attractive for countries, which launder money since risks are reduced for them;

8) Global Terrorism Index shows the level of terrorist activity in countries all over the world. Selection of this indicator is caused by the increase of terrorist acts that influences the country's security. The countries, which launder money, do not attract countries with high terrorism level since there is a risk to lose financial resources. This indicator is a factor-stimulator.

Having formed the set of data, it was analyzed in terms of lack of indicators for some countries. That is why data has been cleared from such observations. As a result, data of 105 countries were chosen for modeling.

After that data was analyzed on the multicollinearity. The results of the paired correlations coefficients are represented in table 1. 
S. Lyeonov, O. Kuzmenko, H. Yarovenko, T. Dotsenko. The Innovative Approach to Increasing Cybersecurity of Transactions Through Counteraction to Money Laundering

The results of the inter-factor correlation prove the dependence between separate factors that is not acceptable for modeling. This dependence may be explained in the following way:

1) such an indicator as Automatic Exchange of Information correlates with Corruption Perceptions Index, Happy Planet Index and Legatum Prosperity Index. The relationship between them is caused either by chance or by the fact that countries with high living standards are obligatory participants of this system;

2) the relationship between the Happy Planet Index and the Legatum Prosperity Index is caused by the fact that these indicators describe similar aspects by the content - happiness and welfare. Since the welfare level is in the domination, its non-linear relationship will be taken into account, so let us leave it in the model;

3) the relationship between the Corruption Perceptions Index, the Happy Planet Index and the Legatum Prosperity Index is significant. It is caused by the fact that there are possibilities and tools to counteract corruption in countries with high indicators of happiness and welfare.

Table 1. The inter-factor correlation for indicators of money laundering attractiveness

\begin{tabular}{ccccccccc}
\hline & GDP & AEOI & CCG & IDP & CPI & GTI & HPI & LPI \\
\hline GDP & 1 & & & & & & & \\
AEOI & 0.1117 & 1 & & & & & & \\
CCG & -0.1205 & 0.2822 & 1 & & & & & \\
IDP & 0.0331 & -0.2546 & -0.1138 & 1 & & & & \\
CPI & -0.0885 & 0.6125 & 0.1225 & -0.2408 & 1 & & \\
GTI & 0.0821 & -0.1059 & 0.0103 & 0.4787 & -0.2662 & 1 & \\
HPI & -0.0112 & 0.5845 & 0.1587 & -0.2125 & 0.7181 & -0.2123 & 1 & \\
LPI & -0.0069 & 0.6576 & 0.1549 & -0.3379 & 0.8973 & -0.3665 & 0.8372 & 1 \\
\hline
\end{tabular}

Source: author's calculations.

Since the regression model is not formed for the proposed methodology, and parameters, for which it causes the instability, are not evaluated, the inter-factor correlation will not influence the general result.

In order to assess the country's economic security regarding the money laundering risk and the terrorist financing risk, we propose a methodology, based on the gravity modelling. It will enable to define possibilities for the financial resources laundering by one country in another country and to define the security level.

It is necessary to normalize data at the first stage. This is due to the fact that indicators, which we use to build models, have a different dimension. That is why they must have a form from 0 to 1 . Besides, one should take into account the fact that the given indicators influence the money laundering risk in different ways. It means that if the indicator grows, it will improve the situation, i.e. reduction of risk and vice versa. Therefore, we deal with a stimulator. If the indicator's changes worsen the situation, i.e. risk grows with indicator's increase, and vice versa, disincentive is considered. We use the absolute normalization equation, that will let us perform it both for stimulators and for disincentive (Kuzmenko, 2014).

$$
x_{i j}^{+}=\frac{x_{i j}}{x_{\max _{j}}}, x_{i j}^{-}=\frac{x_{\min _{j}}}{x_{i j}},
$$

where $\mathrm{x}_{\mathrm{ij}}^{+}, \mathrm{x}_{\mathrm{ij}}^{-}$are normalized values of $\mathrm{j}$-indicator regarding the money laundering and terrorist financing risk level description, for stimulators $(+)$, and for disincentives $(-)$, for i-observed country; $x_{i j}$ is an initial (empiric) value of j-indicator regarding the money laundering and terrorist financing risk level description for i-country; $x_{\text {min }_{j}}$ is a minimum value of the j-indicator regarding the specification to define the laundering risk level for all countries from the research; $x_{\text {max }_{j}}$ is a maximum value of the j-indicator to define the laundering risk level for all countries in the research. 
S. Lyeonov, O. Kuzmenko, H. Yarovenko, T. Dotsenko. The Innovative Approach to Increasing Cybersecurity of Transactions Through Counteraction to Money Laundering

The indicator «Claims on central government», used in the modeling process, is negative and positive. Therefore, the absolute normalization use to this indicator will not enable us to obtain its values from 0 to 1. Since the indicator is disincentive, we will use Savage normalization, that will let to avoid this problem, by formula 2 :

$$
x_{i j}^{-}=\frac{x_{\max _{j}}-x_{i j}}{x_{\max _{j}}-x_{\min _{i j}}} .
$$

At the second stage of the calculation methodology, we will find significant coefficients for the selected indicators. In this regard, the expert inquiry of specialists, who are competent in banking risks, economic security, of scientists, who work over the money laundering issues, is carried out. The hierarchy analysis method in the part of significant coefficients obtaining is used for work with experts.

Experts are suggested to fill the matrix, represented in the form of table 2:

Table 2. The matrix of the factors pair comparison, filled by experts

\begin{tabular}{cccccccc}
\hline & GDP & AEOI & CCG & IDP & CPI & GTI & HPI \\
\hline GDP & 1 & $a_{12}$ & $a_{13}$ & $a_{14}$ & $a_{15}$ & $a_{16}$ & $a_{17}$ \\
AEOI & $1 / a_{12}$ & 1 & $a_{23}$ & $a_{24}$ & $a_{25}$ & $a_{26}$ & $a_{27}$ \\
CCG & $1 / a_{13}$ & $1 / a_{23}$ & 1 & $a_{34}$ & $a_{35}$ & $a_{36}$ & $a_{37}$ \\
IDP & $1 / a_{14}$ & $1 / a_{24}$ & $1 / a_{34}$ & 1 & $a_{45}$ & $a_{46}$ & $a_{47}$ \\
CPI & $1 / a_{15}$ & $1 / a_{25}$ & $1 / a_{35}$ & $1 / a_{45}$ & 1 & $a_{56}$ & $a_{57}$ \\
GTI & $1 / a_{16}$ & $1 / a_{26}$ & $1 / a_{36}$ & $1 / a_{46}$ & $1 / a_{56}$ & 1 & $a_{67}$ \\
HPI & $1 / a_{17}$ & $1 / a_{27}$ & $1 / a_{37}$ & $1 / a_{47}$ & $1 / a_{57}$ & $1 / a_{67}$ & 1 \\
\hline
\end{tabular}

Sources: processed according to (Vitlinskyi et al., 2004).

Matrix is filled through paired comparison of criteria by importance in the scale, represented by table 3 .

Table 3. Scale, by which the paired comparison matrix is filled

\begin{tabular}{|c|c|c|}
\hline $\begin{array}{c}\text { Relative } \\
\text { assessment of } \\
\text { the importance } \\
\text { criterion }\end{array}$ & $\begin{array}{l}\text { Qualitative } \\
\text { assessment }\end{array}$ & Explanation \\
\hline 1 & Equally important & Both elements make the same contribution to achieving the final goal \\
\hline 3 & Not very important & $\begin{array}{l}\text { There are verbal statements in relation to the priority of one element } \\
\text { to another, but these statements are rather inconclusive }\end{array}$ \\
\hline 5 & Essentially important & $\begin{array}{l}\text { There are rather convincing proofs and logic criteria, that one of the } \\
\text { elements is more important (more weighty) }\end{array}$ \\
\hline 7 & Much more important & $\begin{array}{l}\text { There is a convincing proof of one element significance in comparison } \\
\text { with another one }\end{array}$ \\
\hline 9 & Absolutely important & $\begin{array}{l}\text { Awareness of one element's priority in relation to another element is } \\
\text { maximum confirmed }\end{array}$ \\
\hline $2 ; 4 ; 6 ; 8$ & $\begin{array}{l}\text { Intermediate } \\
\text { assessments between } \\
\text { two neighbouring } \\
\text { statements }\end{array}$ & Some compromise is required \\
\hline$\frac{1}{v} ; v=1, \ldots, 9$ & $\begin{array}{l}\text { Inverse values of no- } \\
\text { zero evaluations }\end{array}$ & $\begin{array}{l}\text { Opposite assessments and statements regarding one element } \\
\text { priority in relation to another one }\end{array}$ \\
\hline 0 & Incomparability & There is no sense to compare elements \\
\hline
\end{tabular}

Sources: processed according to (Vitlinskyi et al., 2004). 

Transactions Through Counteraction to Money Laundering

In the process of filling the matrix, if the element $i$ is more important than element $j$, on the crossing point of the i row and $j$ column, the integer number is put in the square ( $i ; j)$, if it is vice versa, the inverse number is put, i.e. fraction. The inverse number to the integer number, or integer number, that is inverse to the fraction, is put in the square $(j ; i)$ on the crossing point of $j$ row and $i$ column.

Then, in every matrix, where expert puts his or her assessments, we will find the weight coefficient for every factor in the matrix row by formula 3 :

$$
\omega_{i}^{k}=\frac{\sqrt[n]{\prod_{j=1}^{n} a_{i j}^{k}}}{\sum_{i=1}^{n} \sqrt[n]{\prod_{j=1}^{n} a_{i j}^{k}}},
$$

where $\omega_{i}^{k}$ is a weight coefficient for every factor $\mathrm{i}$, assessed by k-expert; $a_{i j}^{k}$ - assessment, given by $\mathrm{k}$-expert to i-factor; $\mathrm{n}$ is a number of factors, subjected to assessment.

It is necessary to check coordination of experts through coordination coefficient (formula 4) and paired rank correlation (formula 5) before determination of the general assessment for weight coefficient:

$$
K=\frac{\sum_{j=1}^{n} d_{j}^{2}}{\frac{1}{12}\left[m^{2}\left(n^{3}-n\right)-m \sum_{i=1}^{m} T_{i}\right]},
$$

where $\mathrm{K}$ is a coefficient of concordance; $\mathrm{m}$ is a number of experts, who participate in the research; $\mathrm{n}$ is a number of factors in the research; $d_{j}=\sum_{i=1}^{m} R_{i j}-\frac{\sum_{j=1}^{n} \sum_{i=1}^{m} R_{i j}}{n} ; \mathrm{R}_{\mathrm{ij}}$ - rank of the assessment of $\mathrm{j}$ factor by $\mathrm{i}$-expert; $T_{i}=\sum_{l=1}^{L}\left(t_{l}^{3}-t_{l}\right)$; L is a number of groups of the related (similar) ranks; $\mathrm{t}$ is a number of related ranks in every group;

$$
P_{\alpha \beta}=1-\frac{\sum_{j=1}^{n} \psi_{j}^{2}}{\frac{1}{6} \times\left(n^{3}-n\right)-\frac{1}{12}\left(T_{\alpha}+T_{\beta}\right)}
$$

where $P_{\alpha \beta}$ is a paired rank correlation coefficient; $\psi_{\mathrm{j}}$ is a difference by modulus of the j-factor evaluations ranks, given by experts $\alpha$ and $\beta ; \psi_{j}=\left|R_{\alpha j}-R_{\beta j}\right| ; T_{\alpha}, \mathrm{T}_{\beta}$ are indicators of the related ranks of the experts' assessments $\alpha$ and $\beta$, defined analogically with concordance coefficient; $n$ is a number of factors in the research.

In order to check the statistic significance of the concordance coefficient, Pearson criterion is used and is calculated by formula 6 :

$$
\chi_{p}^{2}=\frac{\sum_{j=1}^{n} d_{j}^{2}}{\frac{1}{12}\left[m n \times(n+1)-\frac{1}{n-1} \sum_{i=1}^{m} T_{i}\right]},
$$

If the concordance coefficient is close to 1 , Pearson criterion will demonstrate its statistic weight, the paired rank correlation coefficients show a strong relationship between the results of the expert inquiry, i.e., the value will be from 0.7 to $1,-$ only under such conditions, we may conclude about coordination between experts. If the experts' opinions are not coordinated, it is necessary to choose experts, whose ideas weakly correlate with others, and to exclude the results of their inquiry.

Having defined the coordination between experts, the arithmetic mean value of the weight coefficients are calculated by formula 7 : 


$$
\omega_{j}=\frac{\sum_{i=1}^{m} \omega_{i}^{k}}{m}
$$

The sum of the obtained coefficients has to be equal to 1 .

Having defined the weight coefficients at the third stage, the integral quantitative evaluation indicator of the country's rating in relation to the money laundering and terrorist financing risk level determination is defined through Minkowski metric (formula 8) (Berzin et al., 2018), which enables to take into account the factors impact based on their positions as stimulators and disincentives:

$$
I R A_{i}=1-\sqrt{\sum_{j=1}^{k} \omega_{j}\left|1-x_{i j}^{+}\right|^{2}+\sum_{j=k+1}^{n} \omega_{j}\left|1-x_{i j}^{-}\right|^{2}},
$$

where $I R A_{i}$ is an integral rating assessment of the laundering risk level specification for i-country; $\omega_{\mathrm{j}}$ - weight coefficients for j-indicator.

Taking into account the fact that in order to assess the money laundering and terrorist financing risk, 7 factors are selected. The formula to calculate the integral indicator (formula 9) is:

$\operatorname{IRA}\left(x_{i}\right)=1-\sqrt{\omega_{1}\left(1-x_{1}^{-}\right)^{2}+\omega_{3}\left(1-x_{3}^{-}\right)^{2}+\omega_{5}\left(1-x_{5}^{-}\right)^{2}+\omega_{7}\left(1-x_{7}^{-}\right)^{2}+\omega_{2}\left(1-x_{2}^{+}\right)^{2}+\omega_{4}\left(1-x_{4}^{+}\right)^{2}+\omega_{6}\left(1-x_{6}^{+}\right)^{2}}$

where $x_{1}^{-}$is a normalized GDP per capita, as a factor- disincentive; $x_{2}^{+}$is a normalized Automatic Exchange of Information, as a factor-stimulator; $x_{3}^{-}$is a normalized Claims on the central government per capita, as a factor- disincentive; $x_{4}^{+}$is a normalized Internally displaced person, new displacement associated with conflict and violence, as a factor-stimulator; $x_{5}^{-}$is a normalized Corruption Perceptions Index per capita, as a factor- disincentive; $x_{6}^{+}$is a normalized Global Terrorism Index per capita, as a factor-stimulator; $x_{7}^{-}$is a normalized Happy Planet Index, as a factor- disincentive.

The obtained integral indicator will vary from 0 to 1 .

The next fourth stage is to build the gravity model of the laundering risk. For this purpose we use the gravitation law and gravitational force equation in the social phenomena, i.e. formula 10:

$$
M_{i j}=k \frac{p_{i} p_{j}}{d_{i j}^{2}}
$$

where $M_{i j}$ is an indicator of interconnection between objects $i$ and $j ; k$ is a concordance coefficient; $p$ is some weight of the object; $d_{i j}^{2}$ is a distance between objects.

This approach was observed in the work of Walter Isard «Location Theory and Trade Theory: ShortRun Analysis» (1954) for international trade in the international economy.

The laundering risk is identified by the following way: one country «attracts» risk operations in another country with force, which is directly proportional to the rating assessment of the laundering risk level in the country, and inversely as a square of the Prosperity Index in the risk operations process implementation (formula 11):

$$
S V A_{k}=\frac{I R A_{k} \cdot I R A_{r}}{d_{k r}^{2}}
$$

where $S V A_{k}$ - quantitative evaluation of (force) interconnection between an observed country and $k$ country in terms of the laundering development; IRA - an integral rating assessment of the $k$-country's 
S. Lyeonov, O. Kuzmenko, H. Yarovenko, T. Dotsenko. The Innovative Approach to Increasing Cybersecurity of Transactions Through Counteraction to Money Laundering

laundering risk level, which transfers risk to the assignment; $I R A_{r}$ an integral rating assessment of the laundering risk in $r$-country, which accepts laundering risk; $d_{k r}$ is a value, which is a normalized difference between welfare of $k$ - and $r$-countries, calculated by equation 12 :

$$
d_{k r}=\left|L P I_{k}-L P I_{r}\right|^{+}
$$

where $P I_{k}$ is Legatum Prosperity Index for country $\mathrm{k} ; P I_{r}$ - Legatum Prosperity Index for country $\mathrm{r}$.

In order to find the difference between countries' welfares we use equation 13 for the natural normalization since this factor is a stimulator for our model:

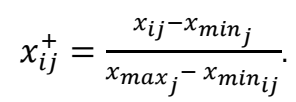

Based on the calculated quantification values (force) of interconnection between countries in terms of laundering risk, the matrix which will enable to assess interconnection between different countries in the world, is formed.

While building this matrix, it is necessary to normalize values again, since the risk quantification must be from 0 to 1 . We use Harrington's risk normalization equation (formula 14), which let us consider distribution of the obtained values, i.e.:

$$
S V A_{k}^{\prime}=\exp \left(-\exp \left(-S V A_{k}\right)\right)
$$

The obtained value will take place from 0 to 1 and will prove that: if the value is close to 0 , the country, where the money is laundered, will have higher attraction risk for money laundering; if the value is close to 1 , the country will have lower attraction level.

Results. Calculations are carried out with the help of MS Excel. At the first stage of the methodology, the normalization of factors-stimulators and disincentives is performed. At the second stage - the expert inquiry results regarding the weight of the factors are obtained. Seven experts-specialists on banking, economic security, scientists, who deal with money laundering problems, were involved. Coordination of experts' opinions is assessed by the concordance coefficient, equal to 0.8076 . Its value is close to 1 , that proves a high level of coordination between experts. The statistic weight of this coefficient is confirmed by Pearson criterion. The obtained criterion is 33.9184 that exceeds table value, equal to 12.5916 .

Coordination between experts' thoughts is confirmed by the calculated coefficient of the paired rank correlation, the results of which are presented in table 4:

Table 4. The matrix of the paired rank correlation of the experts' opinions coordination

\begin{tabular}{cccccccc}
\hline & $\mathbf{1}$ & $\mathbf{2}$ & $\mathbf{3}$ & $\mathbf{4}$ & $\mathbf{5}$ & $\mathbf{6}$ & $\mathbf{7}$ \\
\hline 1 & - & 0.6071 & 0.8571 & 0.7857 & 0.9643 & 0.9643 & 0.5714 \\
2 & & - & 0.7500 & 0.8929 & 0.6786 & 0.5714 & 0.6786 \\
3 & & & - & 0.8571 & 0.8214 & 0.8929 & 0.8571 \\
4 & & & - & 0.8571 & 0.7500 & 0.7857 \\
5 & & & & & - & 0.9286 & 0.6071 \\
6 & & & & & & - & 0.6071 \\
7 & & & & & & - & - \\
\hline
\end{tabular}

Source: author's calculations. 
S. Lyeonov, O. Kuzmenko, H. Yarovenko, T. Dotsenko. The Innovative Approach to Increasing Cybersecurity of Transactions Through Counteraction to Money Laundering

The paired rank correlation has positive values and varies from 0.5714 to 0.9643 . It proves an average and high coordination level between experts. According to results of the experts' coordination assessment, we accept the obtained values as valid ones.

As a result of the inquiry, the averaged assessment of factors is calculated and weights are obtained, which are used in the model (table 5):

Table 5. Weight coefficients for the model's factors

\begin{tabular}{lc}
\hline \multicolumn{1}{c}{ Factors } & Weight \\
\hline GDP per capita (current LCU) & 0.08664 \\
Automatic Exchange of Information & 0.29812 \\
Claims on central government (annual growth as \% of broad money) & 0.08766 \\
Internally displaced persons, new displacement associated with conflict and violence (number of & 0.10479 \\
cases) & 0.19534 \\
Corruption Perceptions Index & 0.19627 \\
Global Terrorism Index & 0.03118 \\
Happy Planet Index & 1.0000 \\
\hline SUM
\end{tabular}

Source: author's calculations.

As a result of the obtained weights, we can see that Automatic Exchange of Information, Corruption Perceptions Index and Global Terrorism Index have the largest impact. It means that these factors have the biggest impact on the money laundering risk assessment. The calculated weights let authors to calculate the integrated indicator of the risk assessment and to find quantification of the value (force) of interconnection between the observed country and $k$-country in terms of the laundering risk.

Authors choose three countries for analysis - Ukraine, Poland and Germany. Table 6 demonstrates results for Ukraine - 10 countries, which are the most attractive for money laundering on the part of Ukraine. Fig. 1 shows the map of proceeds laundering attractiveness for Ukraine in different countries in the world.

Table 6. Top of countries, which are attractive and unattractive for money laundering on the side of Ukraine

\begin{tabular}{clcccc}
\hline № & $\begin{array}{c}\text { Countries with a low level } \\
\text { of attractiveness money } \\
\text { laundering }\end{array}$ & SVA ${ }^{\prime}$ & № & $\begin{array}{c}\text { Countries with a high level } \\
\text { of attractiveness money } \\
\text { laundering }\end{array}$ & SVA $^{\prime}$ \\
\hline 1 & Lesotho & 1.0000 & 95 & Canada & 0.4234 \\
2 & Algeria & 1.0000 & 96 & United Kingdom & 0.4228 \\
3 & Burkina Faso & 1.0000 & 97 & Ireland & 0.4227 \\
4 & Tanzania & 1.0000 & 98 & Sweden & 0.4219 \\
5 & Azerbaijan & 1.0000 & 99 & Netherlands & 0.4189 \\
6 & Lebanon & 1.0000 & 100 & Denmark & 0.4167 \\
7 & Tajikistan & 1.0000 & 101 & Finland & 0.4142 \\
8 & Senegal & 1.0000 & 102 & Iceland & 0.4125 \\
9 & India & 1.0000 & 103 & Switzerland & 0.4105 \\
10 & Kenya & 1.0000 & 104 & New Zealand & 0.4065 \\
\hline
\end{tabular}

Source: author's calculations. 
S. Lyeonov, O. Kuzmenko, H. Yarovenko, T. Dotsenko. The Innovative Approach to Increasing Cybersecurity of Transactions Through Counteraction to Money Laundering



Figure 1. The attractiveness map of the proceeds laundering for Ukraine in different countries in

Source: author's calculations.

the world

Data of Table 6 show that the most attractive countries for money laundering on the part of Ukraine are Canada, United Kingdom, Ireland, Sweden, Netherlands, Denmark, Finland, Iceland, Switzerland and New Zealand, which relate to countries with high level of welfare, counteraction to corruption etc. Thanks to their high development level they attract by abilities to launder money. But these countries introduce high standards of protection and money laundering counteraction to keep the country's economic security that decreases abilities of other countries to launder money and increases the security level.

Such countries as Lesotho, Algeria, Burkina Faso, Tanzania and Azerbaijan do not lead in the economic development and welfare as for Ukraine. That is why the attractiveness level of money laundering in these countries for it is reduced. Such a situation is observed also for other countries with low indicators of economic development and welfare, shown in fig. 1. These countries are not attractive for money laundering, since they have low indicators of welfare, high indicators of corruption, have military conflicts, etc. Therefore, there is a small risk of income loss for the country, which is laundering.

It means that the developed countries thanks to their high living standards, economic development, investment opportunities, real estate purchase, are attractive for the developing countries to launder proceeds. Countries with low welfare level vice versa are less attractive for money laundering, but they give more opportunities to involve funds into the state's economy, without any interest in their origin. The proceeds laundering in such countries relates to the low risk that must attract «potential investors».

The proposed methodology is significant for national regulators' activity. Ukrainian state institutions, such as National Committee on state regulation in the sphere of the financial services markets, State Financial Monitoring Service, National Bank of Ukraine, which regulate problems regarding the financial flows outside Ukraine, have to strengthen the directions for operations tracking, carried out to the countries with high attractiveness level for proceeds laundering. It is possible thanks to some limitations and extension of information regarding economic entities' incomes sources.

Table 7 demonstrates results of calculations by the proposed methodology for Poland -10 countries, which are more attractive for money laundering, and 10 countries, money laundering of which is less attractive on the part of Poland. Fig. 2 represents the map of the attractiveness of proceeds laundering for Poland in different countries in the world. 
S. Lyeonov, O. Kuzmenko, H. Yarovenko, T. Dotsenko. The Innovative Approach to Increasing Cybersecurity of Transactions Through Counteraction to Money Laundering

Table 7. Top countries, which are attractive and unattractive for money laundering on the part of Poland

\begin{tabular}{clcclc}
\hline № & $\begin{array}{c}\text { Countries with a low level } \\
\text { of attractiveness money } \\
\text { laundering }\end{array}$ & SVA $_{\boldsymbol{k}} \mathbf{n}^{\prime}$ & № & $\begin{array}{c}\text { Countries with a high level of } \\
\text { attractiveness money } \\
\text { laundering }\end{array}$ & SVA $\mathbf{k}^{\prime}$ \\
\hline 1 & United Arab Emirates & 1.0000 & 95 & Mali & 0.4281 \\
2 & Chile & 1.0000 & 96 & Guinea & 0.4271 \\
3 & Cyprus & 1.0000 & 97 & Lesotho & 0.4254 \\
4 & Italy & 1.0000 & 98 & Iraq & 0.4211 \\
5 & Uruguay & 1.0000 & 99 & Chad & 0.4188 \\
6 & Croatia & 1.0000 & 100 & Burundi & 0.4149 \\
7 & Panama & 1.0000 & 101 & Angola & 0.4142 \\
8 & Malaysia & 1.0000 & 102 & Afghanistan & 0.4081 \\
9 & Hungary & 1.0000 & 103 & Sudan & 0.4042 \\
10 & Estonia & 0.9997 & 104 & Central African Republic & 0.4004 \\
\hline
\end{tabular}

Source: author's calculations.



Figure 2. The attractiveness map of proceeds laundering for Poland in different countries in the world

Source: author's calculations.

Data from table 7 demonstrate that the most attractive countries for proceeds laundering for Poland are Mali, Guinea, Lesotho, Iraq, Chad, Burundi, Angola, Afghanistan, Sudan, the Central African Republic, which relate to the countries with low level of welfare, corruption counteraction, happiness level etc. This is due to the openness of these countries for money laundering, low standards to counteract the money laundering, ineffective legislation. The developed countries attract countries with low economic development as targeted assistance, financing of terrorism. Since these countries are states with low development level, high terrorism, military conflicts, these circumstances will influence the developed countries' political image reduction. Therefore, regulatory bodies in such countries as Poland, have to be interested in the plan to strengthen the controlling of the funds outflow, which are top attractive countries for money laundering.

Such countries as United Arab Emirates, Chile, Cyprus, Italy, Uruguay, Croatia, Panama, Malaysia, Hungary, Estonia, are less attractive for money laundering on the part of Poland. The same situation is 
S. Lyeonov, O. Kuzmenko, H. Yarovenko, T. Dotsenko. The Innovative Approach to Increasing Cybersecurity of Transactions Through Counteraction to Money Laundering

also for other countries, which have similar indicators of economic development as in Poland, shown in fig. 2. The low attractiveness level is caused by the fact that these are countries, in which stringent standards and conditions are introduced, which warn the money laundering possibilities. Although the risk to lose money for Poland in the money laundering process is low, the stringent conditions regarding the resources inflow limitation from abroad decrease the attractiveness level for money laundering.

Table 8 demonstrates the results of quantitative evaluation calculations of value (force) of interconnection between Germany and 10 countries with low attractiveness and 10 countries with high attractiveness for money laundering. Fig. 3 shows the attractiveness map of proceeds laundering for Germany in different countries in the world.

Table 8. Top countries, which are attractive or unattractive for money laundering on the part of

\begin{tabular}{clccllc} 
& \multicolumn{3}{c}{ Germany } & \\
\hline № & $\begin{array}{c}\text { Countries with a low level } \\
\text { of attractiveness money } \\
\text { laundering }\end{array}$ & SVA $_{\mathbf{k}^{\prime}}$ & № & $\begin{array}{c}\text { Countries with a high level of } \\
\text { attractiveness money } \\
\text { laundering }\end{array}$ & SVA $^{\prime}{ }^{\prime}$ \\
\hline 1 & Canada & 1.0000 & 95 & Chad & 0.4306 \\
2 & Ireland & 1.0000 & 96 & Zimbabwe & 0.4298 \\
3 & Iceland & 1.0000 & 97 & Belarus & 0.4292 \\
4 & Austria & 1.0000 & 98 & Mali & 0.4283 \\
5 & Netherlands & 1.0000 & 99 & Angola & 0.4214 \\
6 & Denmark & 1.0000 & 100 & Burundi & 0.4195 \\
7 & United Kingdom & 1.0000 & 101 & Afghanistan & 0.4186 \\
8 & Switzerland & 1.0000 & 102 & Lesotho & 0.4150 \\
9 & Sweden & 1.0000 & 103 & Sudan & 0.4125 \\
10 & Belgium & 1.0000 & 104 & Central African Republic & 0.4101 \\
\hline
\end{tabular}

Source: author's calculations.

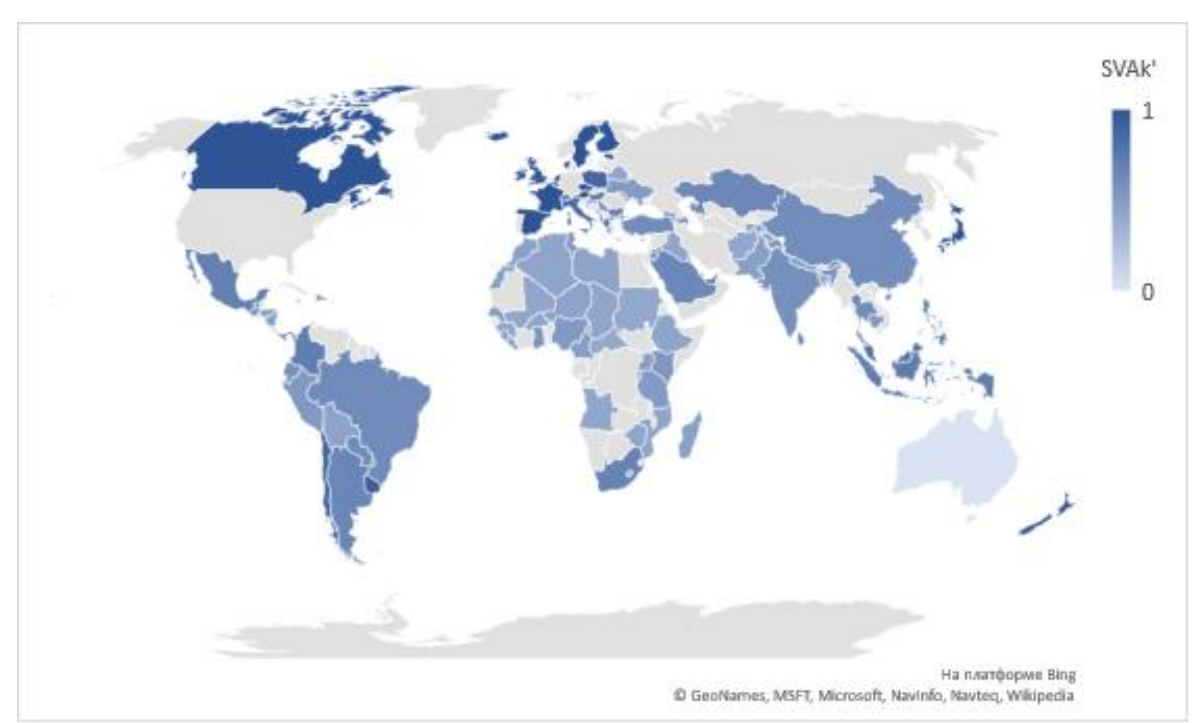

Figure 3. The attractiveness map of the money laundering for Germany in different countries of

Source: author's calculations. the world 
S. Lyeonov, O. Kuzmenko, H. Yarovenko, T. Dotsenko. The Innovative Approach to Increasing Cybersecurity of Transactions Through Counteraction to Money Laundering

Such countries as Canada, Ireland, Iceland, Austria, Netherlands, Denmark, United Kingdom, Switzerland, Sweden, Belgium, are countries with high level of economic development and economic security. Since there are higher protection standards from the inflow of the criminal proceeds in these countries, Germany has lower opportunities for proceeds laundering in these countries. Vice versa, such countries as Chad, Zimbabwe, Belarus, Mali, Angola, Burundi, Afghanistan and others, represented in table 8 and in fig. 3 , are more attractive for criminal proceeds laundering since they do not have stringent limitations for proceeds inflow from abroad and regarding these funds sources. For Germany, the attractiveness level for money laundering in these countries grows, but the risk of losses also increases, since low indicators of the economic development and unstable political situation are peculiar for such countries. If there are such opportunities, Deutsche Bundesbank will be able to develop the strategy to block or to restrict the financial flows for the purpose of money laundering for this country in this group. It will ban the withdrawing of money from the country and reducing their losses via shadowing.

Conclusions. The process of criminal proceeds laundering and financing of terrorism for any country in the world, as a rule, is of an unfavourable nature, especially for the country's economic security. Firstly, this process increases the shadow sector in the economy, since the share of proceeds is shadowed. Secondly, the state's budget loses great funds, since taxes are not paid from criminal proceeds. Thirdly, the criminal proceeds laundering promotes the creation and extension of the fraudulent schemes regarding the financial flows. Fourthly, the investment oufflow is increased and business attractiveness is reduced. Fifthly, the state's expenditures for financial crimes enforcement are increased. Together it leads to undermining of the country's economic security foundations, may influence the terrorist threats on society that finally may cause the country' social security violation.

In order to counteract these phenomena, there is an urgent requirement to increase the level of cyber security in the banking system. It will ensure the safety of transactions, especially those that are associated with other countries. Furthermore, it is necessary to assess the risk that cash flows will not be related to the legalization of funds or the financing of criminal proceeds. Such protection should be based on an assessment of the attractiveness of funds legalization in a particular country through the provision of ethics for relations with countries.

The proposed methodology has to promote the reduction of risks for the state on the part of criminal proceeds laundering and financing of terrorism. Their implementation at the state structures' level will enable to form the informational base to make managerial decisions regarding the country's economic security level growth since it enables to focus on those countries, which are attractive for criminal proceeds laundering. Introduction of this methodology will help to develop new tools of monitoring, analysis, assessment and prediction of financial operations, performance of which is possible outside the country. It will let to create the mechanism of interconnection with other countries regarding the determination of target activities, resources origin etc. In its turn, it requires improvement of the legislative base for financial and credit institutions, economic entities, and persons, who purchase real estate, shares abroad, or relate to other intermediate parties.

The information, which is a result of the proposed methodology, is a base to improve the country's economic policy standards on the part of economic security strengthening and development of the partnership relations with other countries. Also, the proposed methodology will allow to strength the capabilities of the banking cybersecurity system in assessing the risk of income legalization on transactions carried out from different countries. It is possible by the development of new informational technologies for the gathering and exchanging of information not only inside the country regarding financial flows but in the whole world, by new participants' involvement. Implementation of The Automatic Exchange of Information will let to solve problems on tax evasion, but while exchanging the information, the information regarding the cash flow on accounts is not revealed to comply with banking secrecy. In the part of this exchange, it is possible to introduce the electronic identification of the incomes sources and 
S. Lyeonov, O. Kuzmenko, H. Yarovenko, T. Dotsenko. The Innovative Approach to Increasing Cybersecurity of Transactions Through Counteraction to Money Laundering

nature of operations. It will enable to underline operations with doubtful incomes sources and to inform about attempts to perform them to the law enforcement authorities. The similar identification is reasonable to introduce at the bank level, as an obligatory element for banks reporting to the state.

As a result, reducing the risk of financing money laundering and terrorism will have an impact on creating a healthy favorable economic and investment climate in the country. The proposed methodology will allow, through strengthening cyber security measures, to eliminate the negative impact of money laundering processes on the level of economic and social security in the country.

The proposed methodology is planned to be improved in the part where the riskiest economic activities in countries, which are attractive for proceeds laundering, are defined. The study will be oriented to integrate indicators of methodology with indices of other security spheres in the country - political, social and economic. In future, it is planned to introduce the proposed methodology in the activity of the National Commission on state regulation in the financial services markets spheres, State Financial Monitoring Service and National Bank of Ukraine.

Author contribution. Conceptualization, S. L. and O. K.; data curation, H. Y.; formal analysis, O. K. and H. Y.; investigation, O. K. and H. Y.; methodology, S. L., O. K. and H.Y.; resources, H. Y. and T. D.; software, O. K. and H. Y.; supervision, S. L., O. K., H. Y. and T. D.; validation, S. L., O. K., H. Y. and T. D.; visualization, H. Y.; writing - original draft, S. L., O. K., H. Y. and T. D.

Funding. This work is carried out within the taxpayer-funded researches: № 0118 U003574 "Cybersecurity in the banking frauds enforcement: protection of financial service consumers and the financial and economic security growth in Ukraine» and № 0117 U002251 «Improvement of the money laundering counteraction national system in terms of the state's financial and economic security increase», used in Sumy State University. The publication contains the results of studies conducted by President's of Ukraine grant for competitive projects «Development of an automated module prototype for financial monitoring of the economic agents activity to counteract the criminal proceeds legalization» of the State Fund for Fundamental Research.

\section{References}

Andruseac, G. (2015) Economic Security - New Approaches In The Context Of Globalization. CES Working Papers. Centre for European Studies, Alexandru loan Cuza University, 7(2), 232-240.

Kahler, M. (2006) Economic security in an era of globalization: definition and provision. The Pacific Review, 17, 4, 485-502.

Bowman, D., \& Van Kooy, J. (2016) Inclusive work and economic security: a framework. Fitzroy, Vic.: Working Paper, Brotherhood of St Laurence.

Rotaru, M.P. (2009) Economic Security - Organic Dimension of National Security. Germany: University Library of Munich, MPRA Paper17936.

Navarro, P. (2018) Why Economic Security is National Security. RealClearPolitics. Retrieved from https://www.realclearpolitics.com/articles/2018/12/09/why_economic_security_is_national_security_138875.html.

The official site «IFINSEC Financial Sector IT Security Conference and Exhibition». (2019) ifinsec.com. Retrieved from http://www.ifinsec.com/English.aspx.

The official site «EBF Cybersecurity Conference: Managing Risk. Deploying Awareness». (2019) ebf.eu. Retrieved from https://www.ebf.eu/events/cybersecurityconference/.

The official site of the 10 In International Conference on Applied Human Factors and Ergonomics. (2019) ahfe2019.org. Retrieved from http://www.ahfe2019.org/board.html\#cyber.

The call for participation in the 21 st International Conference on Human-Computer Interaction. (2019) 2019.hci.international. Retrieved from http://2019.hci.international/cfp/HCII2019_CFP.pdf.

Hathaway, M.E. (2008) Cyber Security: An Economic and National Security Crisis. Intelligencer, 16, 2, 31-36.

Fernandez, R., Shalaby, S., \& Fetais, N. (2018) Cyber security in Banking: Challenges, Solutions and Trends. kantakji.com. Retrieved from https://www.kantakji.com/media/224665/-cyber-security-in-banking-challenges-solutions-and-trends.pdf.

Leung, R. (2018) Cybersecurity regulation in the banking sector: global emerging themes. researchgate.net. Retrieved from https://www.researchgate.net/publication/328419728_Cybersecurity_regulation_in_the_banking_sector_global_emerging_themes. 
S. Lyeonov, O. Kuzmenko, H. Yarovenko, T. Dotsenko. The Innovative Approach to Increasing Cybersecurity of Transactions Through Counteraction to Money Laundering

Fiorentino, N., Dwyer, K., Hamilton, A., Barney, K., Dwoskin, M., Buggs, E. et al. (2018) The impact of cybersecurity incidents on financial institutions. idtheftcenter.org. Retrieved from https:/www.idtheftcenter.org/wp-content/uploads/2019/02/ ITRC_Generali_The-Impact-of-Cybersecurity-Incidents-on-Financial-Institutions-2018.pdf.

Haigner, S.D., Schneider, F., \& Wakolbinger, F. (2012) Combating money laundering and the financing of terrorism: A survey. Berlin: Economics of Security, Economics of Security Working Paper 65.

Schneider, F. (2017) The Dark Side: Crime Has Gone Global. bertelsmann-stiftung.de. Retrieved from https://www.bertelsmann-stiftung.de/fileadmin/files/Faktencheck/Leaders_Dialogues/Salzburger_Trilog_2017/8_The_Dark_Side. pdf.

Mankiw, N.G. (2018) Principles of Economics. US: Cengage Learning.

Mishkin, F.S. (2016) The Economics of Money, Banking and Financial Markets. Pearson Education.

Buriak, A., Lyeonov, S., \& Vasylieva, T. (2015) Systemically Important Domestic Banks: An Indicator-Based Measurement Approach For The Ukrainian Banking System. Prague economic papers, 24, 6, 715-728. https://doi.org/10.18267/j.pep.53.

Vasylieva, T., Lyeonov, S., Lyulyov, O., \& Kyrychenko, K. (2018) Macroeconomic stability and its impact on the economic growth of the country. Montenegrin Journal of Economics, 1, 159-170. https://doi.org/10.14254/1800-5845/2018.14-1.12.

Lyeonov, S.V., Vasylieva, T.A., \& Lyulyov, O.V. (2018) Macroeconomic stability evaluation in countries of lower-middle income economies. Naukovyi Visnyk Natsionalnoho Hirnychoho Universytetu, 1,138-146.

Vasilyeva, T.A., Leonov, S.V., \& Lunyakov, O.V. (2013) Analysis of internal and external imbalances in the financial sector of Ukraine's economy. Actual Problems of Economics, 12, 176-184.

Popa, C. (2012) Money laundering using the internet and electronic payments. Metalurgia International, 17, 8, 219-220.

Souto, M.A. (2013) Money Laundering New Technologies, FATF and Spanish Penal Reform. Journal of Money Laundering Control, 16(3), 266-268.

Stokes, R. (2013) Anti-Money Laundering Regulations and Emerging Payment Technologies. Banking \& Financial Service Policy Report, 32, 5, 2-6.

Vlcek, W. (2011) Global Anti-Money Laundering Standards and Development Economies: The Regulation of Mobile Money. Development Policy Review, 29, 4, 415-431. https://doi.org/10.1111/j.1467-7679.2011.00540.x

Anderson, R., Barton, C., Böhme, R., Clayton, R., Van Eeten, M.J.G., Levi, M., et al. (2013) Measuring the Cost of Cybercrime. The Economics of Information Security and Privacy, Springer Verlag Berlin Heidelberg, 265-300.

Independent report «2011 report by industry and government on the cost of cybercrime». (2011) gov.uk. Retrieved from https://www.gov.uk/government/publications/the-cost-of-cyber-crime-joint-government-and-industry-report.

Levi, M. (2017) Assessing the Trends, Scale and Nature of Economic Cyber Crime. Crime, Law and Social Change, 67, 3-20 https://doi.org/10.1007/s10611-016-9645-3.

D'Souza, J. (2012) Terrorist Financing, Money Laundering and Tax Evasion: Examining the Performance of Financial Intelligence Units. US: Boca Raton, Taylor \& Francis.

Levi, M., Halliday, T., \& Reuter, P. (2014) Global Surveillance of Dirty Money: Assessing Assessments of Regimes to Control Money Laundering and Compete the Financing of Terrorism. Center on Law and Globalization. orca.cf.ac.uk. Retrieved from http://orca.cf.ac.uk/88168/1/Report_Global\%20Surveillance\%20of\%20Dirty\%20Money\%201.30.2014.pdf

Immordino, G., \& Russo, F.F. (2016) Cashless payments and tax evasion. Center for Studies in Economic and Finance (CSEF) working paper, 445.

Matheson, T. (2011) Taxing financial transactions: Issues and evidence. IMF Working Paper, 54.

Nart, J. (2018) Report on a European Parliament recommendation to the Council, the Commission and the Vice-President of the Commission / High Representative of the Union for Foreign Affairs and Security Policy on cutting the sources of income for jihadists - targeting the financing of terrorism. europarl.europa.eu. Retrieved from http://www.europarl.europa.eu/sides/ getDoc.do?pubRef=-//EP//NONSGML+REPORT+A8-2018-0035+0+DOC+PDF+V0//EN.

Schneider, F., \& Caruso, R. (2011). The (Hidden) Financial Flows of Terrorist and Transnational Crime Organizations: A Literature Review and Some Preliminary Empirical Results. Berlin: Economics of Security Working Paper 52.

Blauvelt, A. (2015) European Integration and Anti-Money Laundering Cooperation. Claremont-UC Undergraduate Research Conference on the European Union 2015, 2014, Article 6. https://doi.org/10.5642/urceu.201401.06

UNODC-31 (2011) Estimating illicit financial flows resulting from drug trafficking and other transnational organized crimes. unodc.org. Retrieved from https://www.unodc.org/documents/data-and-analysis/Studies/llicit-financial-flows_31Aug11.pdf.

Vashchekina, I.V. (2018) Development of international cooperation in the field of combating the legalization of criminal proceeds and the financing of terrorism against the backdrop of external negative. researchgate.net. Retrieved from https://www.researchgate.net/publication/326233851_DEVELOPMENT_OF_INTERNATIONAL_COOPERATION_IN_THE_FIELD _OF_COMBATING_THE_LEGALIZATION_OF_CRIMINAL_PROCEEDS_AND_THE_FINANCING_OF_TERRORISM_AGAINST_ THE_BACKDROP_OF_EXTERNAL_NEGATIVE

Appel, H.E. (2015) Foreign Policy in Pakistan: Bringing Pakistan Into Line with American Counterterrorism Interests. scholarship.claremont.edu. Retrieved from https://scholarship.claremont.edu/cgi/viewcontent.cgi?referer=\&httpsredir=1\&article= 2210\& context $=c m c$ theses.

Bunker, R.J., \& Sullivan, J.L. (2014) Crime Wars and Narco Terrorism in the Americas: A Small Wars Journal - El Centro Anthology. El Centro Anthology. Bloomington, IN: iUniverse.com. 
S. Lyeonov, O. Kuzmenko, H. Yarovenko, T. Dotsenko. The Innovative Approach to Increasing Cybersecurity of Transactions Through Counteraction to Money Laundering

Unita di Informazione Finanziaria (2016) Presentation of the Annual Report of Italy's Financial Intelligence Unit. The Director's Report, Rome, Italy.

European Banking Federation (2016) The europian bankingfederation's response to the European banking authority discussion paper on innovative uses of consumer data by financial institutions.

Groupe d'action financière (2007) Third mutual evalution on anti-money laundering and combating the financing of terrorism Greece. Financial Action Task Force; Groupe d'action financière, Greece.

Tunisian Financial Analysis Committee; Governor of the Central Bank of Tunisia (2017) Tunisia National Risk Assessment of Money Laundering and Terrorist Financing.

Mazloumfard, H., \& Glans, V. (2017) The Influence of Tax Burden on the Profit of Banks in Conditions of Monopolistic Competition: Economic-Mathematical Modeling. Financial Markets, Institutions and Risks, 1, 4, $28-36$.

Krykliy, O., \& Luchko, I. (2018) Model of Stress-testing of Banks' Liquidity Risk in Ukraine. Financial Markets, Institutions and Risks, 2, 2, 123-132.

Subeh, M.A., \& Yarovenko, H. (2017) Data Mining of Operations with Card Accounts of Bank Clients. Financial Markets, Institutions and Risks, 1, 4, 87-95.

Dean, J., Syniavska, O., \& Minenko, S. (2017) Using economic-mathematical modeling in the study of the economic component of terrorism. SocioEconomic Challenges, 1, 2, 103-109.

Kirichenko, L., Radivilova, T., \& Carlsson, A. (2017) Detecting cyber threats through social network analysis: short survey. SocioEconomic Challenges, 1, 1, 20-34.

Vorontsova, A., Lyeonov, S., Vasylieva, T., \& Artyukhov, A. (2018) Innovations in the financing of lifelong learning system: expenditure optimization model. Marketing and Management of Innovations, 2, 218-231. https://doi.org/10.21272/mmi.2018.2-18. Anderson, J.E. (2011) The Gravity Model. Annual Review of Economics, 3(1), 133-160.

Asgharzadeh, M.F., Hashemi, H., \& Frese R.B. (2018) Comprehensive gravitational modeling of the vertical cylindrical prism by Gauss-Legendre quadrature integration. Geophysical Journal International, 1, 212, 591-611. https://doi.org/10.1093/gj/ggx413.

Wee, C.H., \& Pearce, M.R. (2015) Retail Gravitational Models: A Review with Implications for Further Research, In: Lindquist J.D. (eds) Proceedings of the 1984 Academy of Marketing Science (AMS) Annual Conference, Developments in Marketing Science: Proceedings of the Academy of Marketing Science, Springer, Cham, USA.

Kuzmenko, O.V. (2013a) Doslidzhennia problem i vyznachennia rivnia vidkrytosti rynku perestrakhuvannia na osnovi hravitatsiinoho modeliuvannia [Research of problems and determination of the level of openness of the market reinsurance on the basis of gravity modeling]. Visnyk Ukrainskoi akademii bankivskoi spravy, 1, 125-134.

Kuzmenko, O.V. (2013b) Doslidzhennia problem i vyznachennia rivnia vidkrytosti rynku perestrakhuvannia na osnovi hravitatsiinoho modeliuvannia [Research of problems and determination of the level of openness of the market reinsurance on the basis of gravity modeling]. Ekonomika i prohnozuvannia, 3, 134-144.

Ferwerda, J., Kattenberg, M., Chang, H.-H., Unger, B., Groot, L., \& Bikker, A.J. (2011) Gravity Models of Trade-based Money Laundering. DNB Working Paper, 318, 1-28.

Walker, J., \& Unger B. (2009) Measuring Global Money Laundering: «The Walker Gravity Model». Review of Law \& Economics, $5(2), 821-853$.

Unger, B. (2009) The Gravity Model for Measuring Money Laundering and Tax Evasion. Workshop on Macroeconomic and Policy Implication of Underground Economy and Tax Evasion, Bocconi University, Milan, Italy.

Brisard, J.-C., \& Martinez, D. (2016) ISIS Financing in 2015. Center for the Analysis of Terrorism.

World Bank Open Data (2017). data.worldbank.org. Retrieved from https://data.worldbank.org.

Organisation for Economic Co-operation and Development (2017). data.oecd.org. Retrieved from https://data.oecd.org/?_ga=2.69359696.157983792.1546455347-1152323357.1544691649.

Transparency International (2017). transparency.org. Retrieved from https://www.transparency.org/news/feature/corruption _perceptions_index_2017?gclid=EAlalQobChMlusejy-PP3wIVVluyChONdwBEEAAYASAAEglyc_D_BwE.

Institute for economics \& peace (2017). visionofhumanity.org. Retrieved from http://visionofhumanity.org/app/uploads/2017/11/ Global-Terrorism-Index-2017.pdf.

The Legatum Institute (2017). lif.blob.core.windows.net. Retrieved from https:/lif.blob.core.windows.net/lif/docs/defaultsource/default-library/pdf55f152ff15736886a8b2ff00001f4427.pdf?sfvrsn=0.

Happy Planet Index (2017). happyplanetindex.org. Retrieved from http://happyplanetindex.org.

Vitlinskyi, V.V., \& Velykoivanenko, H.I. (2004) Ryzykolohiia v ekonomitsi ta pidpryiemnytstvi [Riskology in economy and entrepreneurship]. Kyiv: KNEU [in Ukrainian].

Kuzmenko, O.V. (2014) Ekonomiko-matematychne zabezpechennia funktsionuvannia perestrakhovoho rynku [Economic and mathematical support of the reinsurance market]. Sumy: Universytetska knyha [in Ukrainian].

Berzin, P., Shyshkina, O., Kuzmenko, O., \& Yarovenko H. (2018) Innovations in the risk management of the business activity of economic agents. Marketing and Management of Innovations, 4, 221-233. https://doi.org/10.21272/mmi.2018.4-20. 
S. Lyeonov, O. Kuzmenko, H. Yarovenko, T. Dotsenko. The Innovative Approach to Increasing Cybersecurity of Transactions Through Counteraction to Money Laundering

С.В. Лєонов, д.е.н., профресор, Сумський державний університет (Україна);

О.В. Кузьменко, д.е.н., професор, Сумський державний університет (Україна);

Г.М. Яровенко, к.е.н., доцент, Сумський державний університет (Україна);

T.В. Доценко, Сумське обласне управління АТ «Ощадбанк» (Україна).

Інноваційний підхід до підвищення рівня кібербезпеки транзакцій через протидію відмивання грошей

Поточним завданням $є$ забезпечення економічної безпеки будь-якої країни в контексті створення ефективних та надійних заходів системи банківської кібербезпеки для протидії відмиванню грошей. Перш за все, ие стосується того, що процеси відмивання грошей та фінансування тероризму негативно впливають на економіку будь-якої країни та знижують рівень економічної безпеки. По-друге, високий рівень відмивання грошей у країні сприяе появі таких негативних процесів, як корупція, вимагання, виробництво наркотиків, контрабанда людей, бандитизм, тероризм, що призводить до посилення криміногенної ситуації в країні та загрожує життю населення країни. По-третє, існуючі заходи щодо кібербезпеки банків своєчасно не впливають на безпеку операцій з метою виявлення незаконно отриманих коштів. Тому саме для цього завдання необхідні зміни та модернізація. Метою статтіє розробка іноваційного підходу до моделювання привабливості країни для відмивання доходів інших країн. Ця методика є одним із інструментів системи кібербезпеки банку для прийняття подальших рішень щодо ризику легалізації. Для вирішення цієї проблеми автори пропонують підхід, який базується на гравітаційному моделюванні. Вісім факторів: валовий внутрішній продукт на душу населення, вимоги до центральної влади, внутрішньо переміщені особи, пов'язані з конфліктом та насильством; автоматичний обмін інфоормацією; індекс сприйняттяя корупиії; глобальний індекс тероризму; індекс процвітання; індекс щастя, пропонується оцінити, використовуючи експертний підхід. Інтегральний показник обчислюється за допомогою метрики Мінковського та з урахуванням нормалізації фракторів. Використовуючи модель гравітації, визначається ступінь привабливості країни для відмивання доходів з боку іншої країни. Для розрахунку було використано дані для 105 країн, та у даній роботі представлені результати для України, Польщі та Німеччини. Як висновок, розвинені країни з високим рівнем добробуту привабливі для країн, що розвиваються, для відмивання грошей; країни з низьким рівнем добробуту, низьким рівнем економічного розвитку та нестабільною політичною ситуацією привабливі для розвинених країн. Запропоновану методологію рекомендується впровадити в діяльність системи кібербезпеки банків. Це дозволить визначити транзакиії тих країн, для яких ризик легалізації високий, та запровадити додатковий моніторинг з огляду на законність їх фінансових джерел. Крім того, модель доцільно використовувати у діяльності регулюючих органів країни, що сприятиме впровадженню стандартів кібербезпеки та підвищить етику фінансових відносин між країнами.

Ключові слова: кібербезпека, відмивання грошей, гравітаційне моделювання, привабливість країни, ризик, експертний підхід, нормалізація, метрика Мінковського.

Manuscript received: 25.07.2019.

(c) The author(s) 2019. This article is published with open access at Sumy State University. 